\title{
0 AVESSO DO MITO: ESCRAVIDÃO E RELAÇÕES DE DEPENDÊNCIA EM O GUARANI
}

http://dx.doi.org/10.11606/issn.2237-1184.v0i29p182-203

Leonardo Affonso de Miranda Pereira

Pontifícia Universidade Católica do Rio de Janeiro (PUC-RJ)

RESUMO

O romance O Guarani, publicado em 1857 por José de Alencar, constitui um poderoso mito inaugural da nacionalidade. No momento em que escrevia, no entanto, Alencar acompanhava os dilemas e debates sobre uma questão aparentemente ausente da trama: a escravidão, que constituía então o nexo fundamental da sociedade brasileira. Entender o modo pelo qual a reflexão sobre o tema se apresenta no romance é o objetivo deste artigo.

\section{ABSTRACT}

The novel O Guarani, published in 1857 by José de Alencar, constitutes a powerful inaugural myth of the brazilian nationality. At the moment of the writing of the novel, however, Alencar followed the dilemmas and debates on an apparently absent issue of the plot: slavery, which was then the fundamental link of Brazilian society. Understanding the way in which the reflection on the theme is presented in the novel is the purpose of this article.

\section{PALAVRAS-CHAVE:}

José de Alencar; romantismo; escravidão; identidade nacional.

\section{KEYWORDS}

José de Alencar; romanticism; slavery; national identity. 


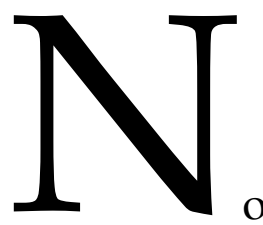

dia $1^{\circ}$ de janeiro de 1857, os leitores do Diário do Rio de Janeiro se depararam com a publicação de um novo romance no rodapé da primeira página do jornal: $O$ Guarani, que se apresentava em seu subtítulo como um "romance brasileiro". Ele vinha ocupar o espaço deixado vago pelo fim do folhetim Cinco Minutos, cuja publicação havia se encerrado dois dias antes. Ainda que nenhum dos dois fosse assinado, não era segredo para os leitores que ambos eram de autoria do jovem José de Alencar, então "redator gerente" da folha. ${ }^{1}$ A separá-los estava a repercussão alcançada por cada um deles: se seu romance anterior não chegou a gerar grande impacto, o novo folhetim, cuja publicação terminou no dia 20 de abril, atraiu atenção imediata. Escrevendo anos depois, Visconde de Taunay se recordava do "entusiasmo que despertou" a obra no momento em que saía no jornal. "O Rio de Janeiro em peso, para assim dizer, lia O Guarani", relembrava, contando ainda que mesmo em cidades distantes da Corte, como São Paulo, o fervor não era menor. Segundo ele, quando o correio chegava trazendo com atraso os novos números do jornal, "reuniam-se muitos e muitos estudantes numa república (...) para ouvirem, absortos e sacudidos, de vez em quando, por elétrico frêmito, a leitura feita em voz alta por algum deles", em cena que diz ter visto também pelas ruas. Para Taunay, teria sido a partir da publicação desse romance que José de Alencar alcançou aquilo que definia como "esse lugar de incontestável supremacia, essa notoriedade que nunca mais deixou de circundar a sua personalidade", constituindo o "seu maior padrão de glória". ${ }^{2}$

As razões do grande interesse despertado pelo romance ligavam-se não apenas ao talento narrativo de seu autor, mas também à proposta que ele explicitamente tentava contemplar: a de constituir um mito da nacionalidade, capaz de afirmar as bases de coesão de uma nação que lutava para afirmar sua originalidade. Escrito em meio às tentativas letradas de definir o caminho de afirmação de uma genuína literatura brasileira, $O$ Guarani apresenta uma proposta de afirmação da matéria nacional. Ao situar a história no primeiro século de colonização portuguesa na América, Alencar abordava o encontro de duas nobrezas

${ }^{1}$ Cf. "Folhetim - Cinco minutos", Diário do Rio de Janeiro, 30 de dezembro de 1856 e "Folhetim O Guarani", Diário do Rio de Janeiro, $1^{\circ}$ de janeiro de 1857.

2 TAUNAY, Visconde de. Reminiscências. São Paulo: Companhia melhoramentos: 1923, pp. 8586. 
distintas em meio à natureza tropical: a de origem europeia, representada pelo fidalgo Dom Antonio Mariz e sua família, da qual fazia parte a jovem Ceci; e a indígena, que tem em Peri seu único representante. Como o próprio autor reconheceria em 1872, tratava-se de uma alegoria da "gestação lenta do povo americano", que saía "da estirpe lusa" para "continuar no novo mundo as gloriosas tradições de seus progenitores" - na configuração de uma narrativa que se apresentava como um poderoso mito da nacionalidade.

Celebrado pela crítica ao longo do século XX como o primeiro romance histórico de José de Alencar, no qual ele dava forma à sua veia nativista ${ }^{3}$, a obra se tornou objeto de uma vasta fortuna crítica, na qual se destacam as análises de Valéria de Marco. Em livro publicado em 1993, ela se propunha a analisar três das produções históricas publicadas por José de Alencar entre 1857 e 1873 - O Guarani, As minas de Prata e Guerra dos Mascates (1873) - de modo a "perscrutar, de um lado, a trajetória que elas constroem da vida da nação e, de outro, a trajetória do olhar que as forjou". Partia, para isso, do pressuposto de que o projeto desses romances estaria "orientado por seu objetivo de escrever a História presente e passada do Brasil, na linguagem que lhe oferecia $o$ Romantismo". ${ }^{4}$ Com tal objetivo, tomava o romance de 1857 como objeto de seu primeiro capítulo. Sem se limitar a reiterar o sentido nacional da alegoria que estruturava seu enredo, a autora busca analisar criticamente seu sentido, investigando o papel que assumiam na trama alguns elementos vistos como acessórios pelos críticos anteriores, como a natureza e as relações de trabalho. Com isso, retomava a ideia de mito configurada desde o momento de sua publicação, dando a ela um sentido mais preciso: o de marca original de afirmação do "rosto mestiço do país". Desse modo, de Marco afirma que "o romance termina ao propor na mescla dos mitos a mestiçagem racial como traço diferenciado e particular do país", o que seria uma maneira de Alencar propor "formas de harmonizar conflitos" no processo de construção da nacionalidade. ${ }^{5}$ Estabelecia assim uma leitura que fazia de $O$ Guarani a primeira configuração de um mito mestiço de nacionalidade que só a partir da década de 1930, com a obra de Gilberto Freyre, alcançaria maior reconhecimento.

Em sentido aproximado, ainda que por caminho diverso, Doris Sommer havia proposto dois anos antes uma análise semelhante sobre o romance, em um livro que tem por objeto algumas das principais narrativas literárias sobre a nacionalidade produzidas na América Latina

\footnotetext{
${ }^{3}$ BOSI, Alfredo. História concisa da literatura brasileira. São Paulo: Cultrix, 1994, p. 138.

${ }^{4}$ MARCO, Valéria de. A perda das ilusões. O romance histórico de José de Alencar. Campinas: Ed. da UNICAMP, 1993, pp. 14-16.

${ }^{5}$ Idem, ibidem, pp. 86-88.
} 
ao longo do século XIX. Ao tratar d'O Guarani, reforça a ideia de que se trata de uma narrativa que aponta para a ideia de que "o Brasil fora fundado quando brancos e índios caíram uns nos braços dos outros e tiveram filhos mestiços", em alusão à suposta descendência de Peri e Ceci. Em sua leitura, o romance aproximaria Alencar dos pressupostos afirmados em 1847 pela monografia sobre as bases da nacionalidade escrita por Von Martius, "um historiador que identificava a mestiçagem como a matriz da brasilidade". 6 Se este apontava para o "encontro" entre brancos, negros e índios como característica singular da nacionalidade, Sommer reconhecia que "Alencar foi evasivo sobre os negros, (...) transformando as três partes em apenas duas". 7 Ainda assim, na análise da autora o sentido do romance de Alencar seria o da afirmação da mestiçagem como forma de lidar com os antagonismos e contradições sociais que marcariam a sociedade brasileira.

Mais preocupado em atentar para o modo como o romance enfrentava alguns dos dilemas de seu tempo, o historiador David Treece havia proposto em 1990 uma leitura diversa, que atentava mais diretamente para seu momento de produção. Para ele, O Guarani pode ser visto como "o romance clássico da Conciliação", no qual Alencar teria expressado em "nível mítico" as bases de uma nacionalidade que o autor tentava então afirmar. Como meio de superar as tensões que marcavam o início do reinado de Pedro II, ele teria dado forma a um mito capaz de expressar "a evolução de uma negociação de poder democrática e contratual entre as forças do Estado e seus sujeitos", na constituição de uma unidade que superasse as fissuras sociais da sociedade brasileira. A execução desse projeto se daria, porém, em bases próximas daquelas afirmadas por De Marco e Sommer - pois era justamente a "atuação cultural da miscigenação" supostamente proposta por Alencar um dos elementos que viabilizaria, para Treece, sua afirmação. Por mais que aponte para a necessidade de entender os mecanismos hierárquicos presentes no romance, acaba por reiterar, assim, a ideia de que ele terminaria com a afirmação de uma "sociedade mestiça", uma "sociedade ideal, perfeitamente integrada e democrática". ${ }^{8}$ Consolidava-se assim, em

\footnotetext{
6 SOMMER, Doris. Ficções de fundação: os romances nacionais da América Latina. Belo Horizonte: Editora UFMG, 2004 [1991], pp. 178-179. Ainda que reafirmada por diversos autores, tal leitura da obra de Von Martius não parece fiel à monografia por ele publicada em 1844 sobre o papel de brancos, negros e índios na formação da nacionalidade - na qual afirma que "do encontro, da mescla, das relações mútuas e mudanças dessas três raças, formou-se a atual população, cuja história por isso mesmo tem um cunho muito particular" (grifos meus). VON MARTIUS. "Como se deve escrever a História do Brasil" in: Revista Trimestral de História e Geografia, tomo 6, n. 24, janeiro de 1844, p. 382.

${ }^{7}$ Idem, ibidem, p. 183.

8 TREECE, David. Exilados, aliados, rebeldes. O movimento indianista, a política indigenista e o Estado-nação Imperial. São Paulo: Edusp, 2008 [2000], pp. 253 e 256.
} 
análises muito diversas entre si, uma leitura do romance como mito fundador da nacionalidade expresso de forma quase naturalista. Sobreviventes dos conflitos que caracterizavam a trama, a jovem Ceci e o índio Peri passavam a representar, em perspectiva bíblica, os colonizadores da nova terra, constituída pelo que haveria de melhor de cada um de seus povos.

Um elemento, no entanto, se mostra ausente dessas leituras habituais sobre o sentido do mito de nacionalidade construído em 1857 por Alencar: a escravidão, que representava então nexo e dilema fundamental da sociedade brasileira. Atento à questão, Alfredo Bosi percebe, em livro de 1992, a força das relações de subordinação na obra de Alencar, ao mostrar como "a figura do índio belo, forte e livre se modelou em um regime de combinação com a franca apologia do colonizador". ${ }^{9}$ Ainda assim, não enxerga nela nenhuma relação com o regime escravista brasileiro no século XIX - em grande parte por partir de uma concepção sobre a escravidão, hegemônica na historiografia brasileira até o final da década de 1980, que a definia como uma relação de completa subordinação, baseada que era na violência. Formulada por cientistas sociais como Florestan Fernandes e Fernando Henrique Cardoso para se contrapor às imagens de equilíbrio e harmonia associadas à escravidão na obra de Gilberto Freyre, tais leituras acabaram por definir a escravidão como simples relação de força, através da qual o escravizado perderia sua própria humanidade. ${ }^{10}$ Sem enxergar no sempre altivo Peri esta condição, Bosi não percebe em $O$ Guarani nenhum comentário sobre a escravidão, vendo o romance como expressão acabada da opção conservadora de Alencar pelo "primitivo natural". 11

Frente a esta concepção de escravidão, não é difícil entender os motivos do silêncio da crítica da posteridade em relação à presença do tema no mito inaugural de Alencar. Ao situar seu enredo no primeiro século da presença portuguesa na América, em um momento no qual o tráfico de africanos escravizados para a América não era ainda tão intenso, o autor de fato não chega a incluir os escravos em sua trama, cuidadoso que era com os registros históricos nos quais baseou sua

\footnotetext{
${ }^{9}$ BOSI, Alfredo. Dialética da colonização. São Paulo: Companhia das letras, 1992, p. 179.

10 Segundo Fernando Henrique Cardoso, um dos autores citados em nota por Alfredo Bosi para apresentar sua concepção sobre escravidão, "o escravo auto-representava-se e era representado pelos homens livres como um ser incapaz de ação autonômica", configurando assim "um ser humano tornado coisa". In: CARDOSO, Fernando Henrique. Capitalismo e escravidão no Brasil meridional. Rio de Janeiro: Paz e terra, 1977, p. 125. Para a formulação desta crítica, ver CHALHOUB, Sidney. Visões da liberdade. Uma história das últimas décadas da escravidão na Corte. São Paulo: Companhia das letras, 1990, pp. 37-43.

11 BOSI, Alfredo. Op.cit., p. 193. Sua adesão a tal concepção sobre a escravidão se expressa claramente em capítulo do mesmo livro intitulado "A escravidão entre dois liberalismos", tanto na análise sobre o tema quanto nas referências bibliográficas nele utilizadas.
} 
escrita. Apesar disso, muitos trabalhos posteriores apontaram para a importância que o tema assumiu em sua produção subsequente - em especial na década de 1870, quando atuou como político e publicista no combate ao ideário abolicionista que se articulou a partir das discussões sobre a lei de 28 de setembro de 1871, conhecida como Lei do Ventre Livre.12 Ao evidenciarem como Alencar fez da escravidão uma das questões centrais de sua produção, tais trabalhos indicam a necessidade de refletir sobre o papel que o tema poderia assumir no mito de nacionalidade forjado por ele em 1857.

Para dar conta deste desafio, é preciso atentar para o modo pelo qual o problema da escravidão era vivido por seus contemporâneos no momento de publicação do romance. Ainda que sem a força dos debates do início da década de 1870, o tema não estava de todo ausente nas reflexões dos homens de letras que tentavam, no período de publicação de $O$ Guarani, afirmar as novas bases da nacionalidade. A própria aprovação, em setembro de 1850, da Lei Eusébio de Queiroz (que efetivamente fazia valer as determinações de outra lei aprovada em 1831 sobre o fim do tráfico de africanos escravizados) ${ }^{13}$, obrigava os homens públicos a colocarem em pauta estratégias de manutenção e reprodução do sistema escravista.

Para além de configurar a centralidade do tema no período, no entanto, cabe tentarmos entender o modo pelo qual os homens e mulheres contemporâneos a Alencar, que eram seus leitores privilegiados, entendiam a questão da escravidão. Como mostram muitos trabalhos sobre a escravidão brasileira publicados a partir da década de 1980, a escravidão se configurava em meados do século XIX como elemento estruturante da vida social do país - marcando a expressão máxima de relações de dependência que, com forças e formas variadas, organizavam toda a sociedade. ${ }^{14}$ Empenhados em compreender a lógica dos próprios escravos, tais trabalhos acabaram por se afastar da imagem de completa subordinação que definia até então a escravidão através de investigações empíricas densas, que expunham as estratégias de negociação e resistência cotidiana dos africanos escravizados e de seus

\footnotetext{
12 Cf. Sidney Chalhoub, Machado de Assis, historiador. São Paulo: Companhia das letras, 2003; Hebe Cristina da Silva, Representações do negro e da escravidão em José de Alencar - o diálogo entre o político e o romancista. Dissertação de Mestrado, IEL/UNICAMP, 2004; Tâmis Parron, "Introdução", em José de Alencar, Cartas a favor da escravidão, São Paulo: Hedra, 2008; e Dayane Façanha, Política e escravidão em José de Alencar, São Paulo: Alameda, 2017.

13 "Parte oficial - Ministério da Justiça - Lei n. 581 de 4 de setembro de 1859", Correio Mercantil, 6 de setembro de 1850 .

${ }^{14}$ Cf. Sidney Chalhoub, 2003.
} 
descendentes. ${ }^{15}$ Mostravam com isso que, longe de se definir somente pela força, a escravidão era uma relação de domínio constituída nos princípios de uma ideologia paternalista, que definia o código que mediava os conflitos e antagonismos sociais. Do ponto de vista dos senhores, era esta, muito mais do que a violência, que garantia a subordinação de seus escravos - o que os fazia ver o mundo como expressão de sua própria vontade, à qual todos deveriam obedecer. Para os próprios escravizados, entretanto, tal ideologia se apresentava como o código dentro do qual eles podiam forjar suas estratégias de luta pela liberdade. ${ }^{16}$

É sob o prisma dessas novas leituras sobre a escravidão que a importância do tema em $O$ Guarani pode se evidenciar. Por mais que estivesse ainda distante da preponderância que os próprios escravos ganhariam em algumas de suas obras posteriores, Alencar não deixaria fora de seu mito de nacionalidade o elemento que se apresentava então como nexo fundamental da sociedade brasileira. Reconhecida a ausência de personagens escravos no romance, cabe tentarmos compreender de que maneira e por que meios José de Alencar pode ter feito da escravidão um dos elementos estruturantes de sua trama.

\section{A verdade do mito}

A tentativa de entender como um romance no qual não há personagens escravos pode ter sido um meio de seu autor refletir sobre a escravidão passa, antes de mais nada, pela reflexão sobre o tipo de relação que aquela obra estabelece com o princípio de realidade. Ao longo das décadas finais do século XIX começou a se afirmar entre os literatos brasileiros um tipo de realismo que, segundo as observações atentas de Machado de Assis em sua crítica a Eça de Queiroz, se apresentava como uma "reprodução fotográfica e servil das coisas mínimas e ignóbeis". ${ }^{17}$ A partir da necessidade que viam de aproximar a literatura da vida social, muitos autores passaram a fazer da realidade imediata a matéria principal de sua imaginação. Se em 1878 a crítica do romancista se voltava para os exageros desse realismo "sem rebuço, sem atenuações, sem melindres", seu artigo dava a ver o processo de afirmação de um novo paradigma literário que se tornou hegemônico já no início do século $X X$, no qual a verossimilhança ganhava relevo na

${ }^{15}$ Cf. Sidney Chalhoub, 2003; J.J. Reis e Eduardo Silva. Negociações e Conflito: a resistência negra no Brasil escravista. São Paulo: Companhia das letras, 1989 e Silvia Lara, Campos da Violência. Escravos e senhores na capitania do Rio de Janeiro, 1750-1808. Rio de Janeiro: Paz e terra, 1988.

16 Segundo Sidney Chalhoub, "a vigência de uma ideologia paternalista não significa a inexistência de solidariedades horizontais e, por conseguinte, de antagonismos sociais". In: CHALHOUB, 2003, p. 47.

17 ASSIS, Machado de. "Eça de Queiroz: o Primo Basílio". O cruzeiro, 16 de abril de 1878. 
constituição da boa literatura. ${ }^{18}$ Lido $O$ Guarani na perspectiva de tal paradigma, afirma-se tanto a crença na aposta de José de Alencar na mestiçagem - baseada no fato de que Peri e Ceci são os únicos sobreviventes do dilúvio que destruiu a comunidade do Paquequer, sendo por isso tomados como povoadores da nova terra - quanto a suposição de que o romance, por não incluir escravos, não trata da escravidão.

Em 1857, no entanto, eram outras as preocupações de Alencar. Com apenas 27 anos, ele era ainda um jovem pretendente a literato que tentava afirmar seu talento. Esta afirmação dependia, no entanto, de sua capacidade de diálogo com as questões que marcavam o campo literário brasileiro do período. Estas seriam condensadas, quatro anos depois, por Joaquim Norberto de Souza. Literato e membro do ainda novo Instituto Histórico e Geográfico Brasileiro, ele publicou em 1861 um artigo sobre a "originalidade na literatura brasileira", no qual fazia um balanço dos fatores que vinham alimentando a constituição das letras nacionais. ${ }^{19} \mathrm{~A}$ partir da ideia de que a arte seria universal, ele começava por afirmar que "a originalidade da literatura de qualquer nação se demonstra por si mesma". Longe de ser fruto da comparação com a produção de outros países, ela se afirmaria a partir da tematização de certos elementos capazes de determinar o sentido singular da literatura produzida por determinada nação - como a "cor local que provém da natureza e do clima do país", os "costumes, usos e leis da sociedade", as "inspirações da religião que segue o povo" e a "história e tradições que ligam o presente ao passado". Ainda que outros escritores pudessem discordar do modo como Joaquim Norberto formulava a relação dos literatos com esses quatro elementos, seu balanço mostrava que era a busca dessa cor local que marcava a produção literária brasileira, a partir de fatores como a natureza, a cultura, a religião e a história.

Foi na tentativa de responder a esse desafio que, em 1856, o já renomado Gonçalves de Magalhães publicou um poema épico intitulado A Confederação dos Tamoios. ${ }^{20}$ Como indicava o título, tratava-se de uma tentativa de tematizar poeticamente a disputa entre portugueses e franceses nos primeiros tempos da presença europeia na América, em conflito que durou treze anos e terminou com a vitória dos portugueses graças à aliança com alguns povos indígenas. Tomado pelo poeta como

18 Cf. Leonardo Pereira, "A realidade como vocação: literatura e experiência nas últimas décadas do Império". In: GRINBERG, Keila; SALLES, Ricardo (orgs.). O Brasil imperial (18701890). Rio de Janeiro: Civilização brasileira, 2009.

${ }^{19}$ SILVA, Joaquim Norberto de Sousa e. "Originalidade da Literatura Brasileira", Revista Popular, n. 9, jan-mar 1861 apud SILVA, J. N. S. História da literatura brasileira e outros ensaios. In: SOUZA, Roberto Acízelo de (org.). Rio de Janeiro: Zé Mário editor, 2002, pp. 160-161.

${ }^{20}$ MAGALHÃES, Gonçalves de. A Confederação dos Tamoios, Rio de Janeiro: Tip. dous de dezembro, 1856. 
símbolo de fundação da nacionalidade, tal aliança era tematizada como forma de dar conta de desafios semelhantes àqueles que seriam propostos por Joaquim Norberto: o estabelecimento de uma literatura baseada na história nacional, que incorporasse a natureza tropical, os costumes e culturas dos povos nativos e a religiosidade que estaria na base dessa união. ${ }^{21}$ Como um dos expoentes do grupo de intelectuais ligadas ao ainda jovem Imperador do Brasil, temperava tudo com a saudação à Coroa - celebrada na visão de futuro de um índio que vislumbrava a figura do monarca: "como o povo o ama! Como o guarda"!22 De forma explícita, tratava-se de uma tentativa de estabelecer a "epopeia nacional do século de Pedro II", como notava o historiador Francisco Adolfo de Varnhagen em carta enviada ao próprio Imperador. ${ }^{23}$

Nesta mesma carta, porém, o próprio Varnhagen afirmava que o poema estava "mui longe de poder" aspirar às honras que pretendia alcançar, apontando erros históricos e imprecisões que maculariam a relação que ele pretendia estabelecer com a história da nação. Nesse ponto, secundava as opiniões expressas por uma série de artigos publicados pouco antes no Diário do Rio de Janeiro por um certo Ig, pseudônimo com o qual o jovem José de Alencar se lançava na arena das grandes discussões públicas. Ao contrário de Varnhagen, ele afirmava tratar-se de "um belo assunto" que, ao permitir que se tematizasse tanto a "grandeza de uma raça infeliz" quanto as "cenas da natureza esplêndida da nova terra", daria "uma divina epopeia, se fosse escrita por um Dante". ${ }^{24} \mathrm{Na}$ visão de Alencar, não parecia ser o caso. O problema seria a falta de verdade de seus quadros e descrições - como as das "virgens índias" que, segundo Alencar, poderiam "figurar em um romance árabe, chinês ou europeu", tal sua falta de verossimilhança. Era assim por conta da falsidade dos quadros sobre a história e os costumes que marcaram a colonização portuguesa na América que Alencar criticava o poema de Magalhães, descrito por ele como um mero exercício de imaginação e estilo.

A polêmica levou à publicação de vários artigos em defesa de Magalhães. Segundo lembrava Machado de Assis em 1887, "a crítica ocupou a atenção da cidade durante longos dias, objeto de réplicas, debates, conversações" 25 , na indicação da centralidade do debate a respeito da relação entre literatura e nacionalidade no período. Frente ao

\footnotetext{
${ }^{21}$ Em um dos versos, escreve Magalhães: “Dai-me a cruz! - brada o índio mesmo em sonho/ Dai-me a cruz! A seus pés quero prostrar-me". In: MAGALHÃES, Gonçalves de. Op.cit., p. 190. ${ }^{22}$ MAGALHÃES, Gonçalves de. Op.cit., p. 185.

23 "Carta de Varnhagen a D. Pedro II datada de 24/09/1856". In: MOREIRA, Maria Eunice e BUENOS, Luis (orgs.). A Confederação dos Tamoios. Edição fac-similar seguida da polêmica sobre o poema. Curitiba, Ed. UFPR, 2007, p. CXLV.

${ }^{24} \mathrm{Ig}$ (José de Alencar), "Carta primeira”, Diário do Rio de Janeiro, 19 de junho de 1856.

${ }^{25}$ ASSIS, Machado de. Obra completa. Rio de Janeiro: Nova Aguilar, vol. 3, 1994.
} 
interesse despertado pelo tema, o próprio José de Alencar, através de seu pseudônimo, colocava-se como postulante a executar a tarefa na qual Gonçalves de Magalhães havia falhado. Em uma das últimas cartas que publicou, confessava:

Houve um tempo em que me ocupei, com prazer e até com entusiasmo, das cousas velhas do meu país; em que lia com mais satisfação do que um romance, as crônicas de Simão de Vasconcelos, de Rocha Pita, de Pizarro, de Brito Freire, e as viagens de Max (...). Deste tempo conservo ainda muitas ideias graciosas, que não escrevo porque tenho medo de tirar-lhes o encanto da simplicidade; porque não me reconheço com força de reproduzi-las como as sinto; e também porque não tenho ânimo de prosseguir num trabalho sério. ${ }^{26}$

Alencar indicava o requisito necessário para quem quisesse realizar a contento uma obra capaz de representar efetivamente a literatura nacional: o efetivo conhecimento da história do país, expressa nos escritos de historiadores e cronistas coloniais. Ainda que alegasse não o fazer por medo de deturpar seu "encanto de simplicidade", poucas semanas separam esta coluna do início da publicação de O Guarani no folhetim do Diário do Rio de Janeiro. Era assim o conhecimento sólido da história nacional que amparava a pretensão de Alencar de dar forma a uma obra literária capaz de representar efetivamente a nacionalidade.

Apesar do apego do romancista à verdade da história, o modo pelo qual ele pretendeu realizar esta tarefa afastava-o de qualquer princípio direto de realidade. É o que ele fez questão de deixar claro já de início, no prólogo que antecedeu a publicação do romance no jornal, no qual retomava o diálogo estabelecido em obra anterior com sua "prima". Dizendo que esta havia gostado de sua história, afirma que ela lhe teria pedido "um romance", por achar que ele poderia "fazer alguma coisa neste ramo de literatura" - certeza que o autor se apressa em negar:

Engana-se; quando se conta aquilo que nos impressionou profundamente, o coração é que fala; quando se exprime aquilo que outros sentiram ou podem sentir, fala a memória ou a imaginação. Esta pode errar, pode exagerar-se; o coração é sempre verdadeiro, não diz senão o que sentiu; e o sentimento, qualquer que ele seja, tem a sua beleza. ${ }^{27}$

Da distinção que faz entre o que diz "o coração" e aquilo que expressa "a memória ou a imaginação" explicita-se o sentido de sua

\footnotetext{
${ }^{26} \mathrm{Ig}$ (José de Alencar), "Sétima carta", Diário do Rio de Janeiro, 12 de agosto de 1856.

27 "O Guarani", Diário do Rio de Janeiro, $1^{\circ}$ de janeiro de 1857. As partes ilegíveis do prólogo foram consultadas em ALENCAR, José de. O Guarani. Cotia-SP: Ateliê editorial, p. 45.
} 
resposta. Ainda que se dissesse capaz de tratar de seus próprios sentimentos, afirmava-se inseguro para escrever uma história baseada em relatos alheios, não se julgando por isso "habilitado a escrever um romance".

Como era evidente para os leitores contemporâneos, tal negativa era, ela mesma, simples recurso narrativo. Logo após esta explicação inicial, o autor deu continuidade ao seu prólogo, anunciando o sentido geral da obra que apresentava ao público:

Entretanto, para satisfazê-la, quero aproveitar as minhas horas de trabalho em copiar e remoçar um velho manuscrito que encontrei em um armário desta casa, quando a comprei. Estava abandonado e quase todo estragado pela umidade e pelo cupim, esse roedor eterno, que antes do dilúvio já se havia agarrado à arca de Noé, e pôde assim escapar ao cataclisma.

De modo aparentemente casual, o romancista apresentava a chave de compreensão de seu romance. Após afirmar que não possuía o dom da "imaginação", propunha-se a apresentar um relato que seria a simples adaptação de um manuscrito antigo. É na datação desse manuscrito, no entanto, que se revela o sentido de sua produção: ainda que ligado à verdade, como ele mesmo cobrara de Gonçalves de Magalhães, tratava-se de uma verdade mítica, ligada ao início dos tempos, como sugerido pela tradição bíblica. Alencar explicitava, com isso, o senso de imaginação ao qual deveria se submeter a verdade do relato - o que o leva a advertir o leitor de que encontraria no romance "cenas que não são comuns atualmente", por não serem baseadas em um princípio direto de realidade, mas que estariam em conformidade com a proposta geral da obra.

Explicitava-se, com isso, a proposta de $O$ Guarani. Ainda que o recheasse de notas de rodapé com referências de historiadores e cronistas, era essa verdade mais profunda sobre a nacionalidade que Alencar buscava, afastando-se de um simples inventário do real. Nesta concepção, o desafio de enfrentar a realidade nacional que marcava os escritores de sua geração deveria ser encarado com as armas da imaginação. É o que faz no seu mito inaugural: por mais que, fiel à verdade da história, não tenha incluído escravos em sua trama, nem por isso deixaria de refletir nela sobre a questão que se apresentava então como desafio central para qualquer tentativa de afirmação da nacionalidade. Resta entender, no desenrolar do próprio romance, o modo pelo qual isso se dá. 


\title{
O mundo senhorial do Paquequer
}

O primeiro capítulo de O Guarani, intitulado "O Cenário", dedicase a apresentar o mundo no qual se desenvolveria a trama. Já em suas primeiras páginas, apresenta por isso a densa floresta que envolvia o rio Paquequer, na Serra dos Órgãos. Através da apresentação do aspecto natural deste rio, um dos afluentes do majestoso rio Paraíba, o autor começa a explicitar a lógica de seu romance:

\begin{abstract}
Dir-se-á que, vassalo e tributário desse rei das águas, o pequeno rio, altivo e sobranceiro contra os rochedos, curva-se humildemente aos pés do suserano.

Perde então a beleza selvática; suas ondas são calmas e serenas como as de um lago, e não se revoltam contra os barcos e as canoas que resvalam sobre elas; escravo submisso, sofre o látego do senhor. ${ }^{28}$
\end{abstract}

De forma aparentemente casual, Alencar começava por valorizar a força da natureza tropical, contemplando com isso um dos elementos elencados por Joaquim Norberto em seu programa para a afirmação da literatura nacional. Para além de configurar simples pano de fundo, no entanto, o modo pelo qual apresenta a natureza ajuda o autor a configurar a própria lógica de seu enredo. Por mais "altivo" que fosse, o rio Paquequer era descrito como simples subordinado do Rio Paraíba, cuja grandeza ajudava a ressaltar. Frente à força de seu "suserano", perdia a aparência selvagem, e se tornava calmo e sereno. $\mathrm{O}$ princípio da subordinação, que muitos autores apontam como característica central da ideologia paternalista que sustentava a escravidão e organizava a sociedade brasileira no século $\mathrm{XIX}^{29}$, configurava-se assim como característica natural da paisagem na qual o autor ambientava o romance. Se restasse alguma dúvida sobre o sentido do paralelo sugerido com o mundo social, Alencar tratava de dirimi-la ao definir o Paquequer como um "escravo submisso" de seu senhor, à cuja força estaria sujeito. ${ }^{30}$

Além de apresentar o cenário nacional, este capítulo inicial tratava também de situar a trama no ano de 1604, quando "a civilização não tivera tempo de penetrar o interior" em que se localizava o espaço descrito, e de descrever a "casa larga e espaçosa" que ficava às margens

\footnotetext{
${ }^{28}$ ALENCAR, José de. O Guarani. Rio de Janeiro: Empresa nacional do diário, 1857, pp. 3-4.

${ }^{29}$ Cf. Sidney Chalhoub, 2003.

30 A afirmação do princípio da subordinação através da descrição da natureza havia sido já apontada por Valéria de Marco, para a qual "a hierarquia da ordem natural impõe-se para o leitor com absoluta nitidez, pois ela se consolida através da analogia com esferas de poder da ordem social"; e por David Treece, para quem "a relação entre os dois rios parece confirmar essa estrutura hierárquica de poder". MARCO, Valéria de. Op.cit., p. 23; e TREECE, David. Op. cit., p. 245.
} 
do Paquequer. Situada na beira de um precipício, onde estava colocada "uma ponte de madeira solidamente construída", a propriedade era "protegida de todos os lados por uma muralha de rocha cortada a pique", valendo-se das características naturais do terreno "para criar meios de segurança e defesa". Aliava, desse modo, os princípios de construção geralmente associados aos castelos da Europa medieval a uma clara atenção às peculiaridades da natureza local. Tal lógica se repete nas descrições das construções situadas dentro dos muros - seja o casarão, que tinha sobre sua porta principal um "brasão de armas", ou os "dois grandes armazéns ou senzalas" situados no terreno que ficava ao seu fundo, que serviam de moradia aos dependentes que trabalhavam na propriedade. ${ }^{31}$ Ao apresentar o pequeno enxerto de civilização localizado em meio à mata, o capítulo inicial do romance tratava de evidenciar o eixo estruturante do enredo: a tensão entre uma civilização de base europeia e as contingências naturais e sociais do mundo local, que não permitiam que esta se configurasse de modo integral.

Apresentado o cenário, o segundo capítulo se voltava para a caracterização de seus habitantes, privilegiando a figura de D. Antonio Mariz, o dono da propriedade. Descrito como um "fidalgo português de cota d'rmas e um dos fundadores da cidade do Rio de Janeiro", ele era apresentado a partir do princípio que dava o título do capítulo: sua "lealdade", que o levou a se mudar para aquela localidade no momento em que a coroa portuguesa passou para as mãos do espanhol Felipe II. Fiel ao Rei de Portugal, o valoroso nobre construiu em 1593 no terreno que havia ganho do governador Mem de Sá a habitação descrita acima, caracterizada como "um verdadeiro solar de fidalgo português". Nele residiam, além de D. Antonio, sua mulher D. Lauriana, uma "dama paulista imbuída de todos os prejuízos da fidalguia; o filho D. Diogo de Mariz, visto como sucessor do pai; a jovem filha Cecília, a "deusa desse pequeno mundo"; e a sobrinha Isabel, "fruto dos amores do velho fidalgo com uma índia que havia cativado em uma de suas explorações". Naquela propriedade que o próprio autor associa a "um castelo feudal da Idade Média", o fidalgo pretendia estabelecer "um fragmento de Portugal livre", de modo a reafirmar sua devoção à Coroa portuguesa. ${ }^{32}$

A dificultar sua tarefa, no entanto, estava não apenas a exuberância da natureza tropical, mas também a presença na região de "tribos selvagens" que costumavam "fazer correrias e atacar os brancos à traição". Para defender-se delas, D. Antonio contava não apenas com as características da construção, mas também com o trabalho de "aventureiros pobres, desejosos de fazer fortuna rápida" que se

\footnotetext{
${ }^{31}$ ALENCAR, José de. Op. cit., capítulo 1, pp. 7-8.

32 Idem, ibidem., parte I, capítulo 2, pp. 15-19.
} 
estabeleceram na propriedade. "O fidalgo os recebia como um ricohomem que devia proteção e asilo aos seus vassalos", explicava Alencar, a demonstrar a relação de subordinação estabelecida entre eles. Por dentro dessa lógica, D. Antonio Mariz impunha a tais dependentes "uma disciplina militar rigorosa, mas justa: a sua lei era a vontade do chefe", o que obrigava tais dependentes a uma "obediência passiva". Nesse quadro, a severidade do fidalgo "tinha apenas o efeito salutar de conservar a ordem, a disciplina e a harmonia", constituindo a base de coesão daquela pequena comunidade. ${ }^{33}$

A ênfase de Alencar sobre o tema mostrava que o princípio da subordinação se configurava, nesses dois capítulos iniciais, como a base sobre a qual se desenvolveria o romance. "- Aquele que dá as ordens, sabe o que faz; a nós cumpre obedecer", afirma um de seus mais fiéis dependentes no meio da trama, em raciocínio reafirmado até sua parte final:

- Não é só a nossa vida que temos a defender, e essa pouco vale para cada um de nós; é sim a pessoa daquele que confia em nosso zelo e coragem, e mais ainda o sossego de uma família honrada que todos prezamos ${ }^{34}$.

Nas palavras do dependente, para o qual a vida do senhor valeria mais do que a dele mesmo, configurava-se uma perspectiva de subordinação e obediência que era apresentada como a base de sustentação daquela comunidade. Descrita como expressão acabada da vontade de seu senhor, ela tinha na ideologia da dependência seu principal sustentáculo, expressa tanto na ordem natural da localidade quanto em sua organização social. Não parece um acaso, por isso, que já em seu primeiro capítulo Alencar tenha descrito aquele mundo como "uma miniatura" 35: escrito em meio a uma sociedade cujo nexo ideológico fundamental era o mesmo princípio de subordinação, que na lógica dos senhores de escravos se expressava em perspectiva semelhante àquela descrita por D. Antonio Mariz e seus agregados, o mundo do Paquequer se apresentava para os leitores contemporâneos como uma representação ideal dessa lógica. Era a partir dele que Alencar começava a edificar seu mito inaugural da nacionalidade.

\footnotetext{
${ }^{33} I d .$, ib., parte I, capítulo 2, pp. 15-17.

${ }^{34} I d$., ib., parte I, capítulo 8, p. 82; e parte III, capítulo 1, pp. 11 e 82.

${ }^{35} I$ d., ib., parte I, capítulo 2, p. 7.
} 


\section{A gramática da escravidão}

Em que pese a associação das casas habitadas pelos dependentes de D. Antonio Mariz às "senzalas", na parte inicial do romance a escravidão não chega a aparecer de forma mais direta. A partir do quarto capítulo, no entanto, começam a ser apresentados os personagens principais do enredo: a jovem Ceci, filha menor de D. Antonio, e o selvagem Peri, um índio guarani que vivia nas imediações da propriedade. Através das palavras e atitudes dos dois, configurava-se o sentido do comentário sobre o regime escravista presente no romance.

Peri é o primeiro a ser apresentado, em capítulo dedicado à caçada de uma onça. A descrição feita sobre ele ressalta sua boa índole. Vestido com uma "túnica de algodão, a que os indígenas chamavas aimará", Peri tem pele "cor de cobre", "cabelos pretos cortados rentes" e uma "boca forte, mas bem modelada e guarnecida de dentes alvos". Com "alta estatura" e "mãos delicadas", ele surge como a representação acabada daquilo que Alencar define como uma "beleza inculta", forjada a partir "da graça, da força e da inteligência". Após caçar sua presa com grande agilidade, preparou sua "selvagem refeição", que finalizou "com alguns favos de mel" que serviram de sobremesa antes de lavar "as mãos, o rosto e os pés" em um córrego próximo. Contraposto a outro índio que aparece ao final do mesmo capítulo "completamente nu, ornado apenas com uma trofa de penas amarelas", Peri é apresentado como uma espécie de "rei das florestas americanas", cuja nobreza se afirmava tanto em sua aparência quando em sua educação inata. ${ }^{36}$ " - É um cavalheiro português no corpo de um selvagem", explicava mais à frente o próprio D. Antonio Mariz, no reconhecimento da grandeza que via no "caráter desse índio". ${ }^{37}$

Já Ceci, filha do fidalgo, é apresentada no capítulo seguinte como uma "linda moça" com "grandes olhos azuis", "lábios vermelhos e úmidos" e a "tez alva e pura como um froco de algodão". Esta beleza europeia era temperada, contudo, pela sensibilidade nativa de uma jovem que cresceu em um meio tropical. "- Já me habituei tanto a ver estas árvores, este rio, esses montes, que quero-lhes como se me tivessem visto nascer", explicava a própria Ceci - cujos lábios eram descritos como "uma dessas flores de gardênia dos nossos campos", em alusão à flora local que Alencar faz questão de explicar em nota de rodapé. Sem restringir-se aos padrões estéticos do velho mundo, a jovem apresentava assim uma beleza original, que transformava sua aparência em uma "mistura de luxo e simplicidade". 38 Nobre como o pai, não só por direito,

\footnotetext{
${ }^{36} I d$., ib., parte I, capítulo 4, pp. 32-42.

${ }^{37} I d$., ib., parte I, capítulo 7, p. 75.

${ }^{38} I d$., ib., parte I, capítulo 5, pp. 43-48.
} 
mas também por suas atitudes, a jovem herdeira do Paquequer era definida como a representante de uma nobreza europeia já familiarizada com a realidade natural do novo mundo - em relação ao qual, ao contrário da mãe, demonstrava grande afeição.

Embora os dois personagens sejam caracterizados com atributos de nobreza, a relação entre eles está longe de se configurar de modo igualitário. Desde o início do romance evidencia-se a devoção absoluta de Peri pela filha de D. Antonio Mariz. Segundo o comentário implicante de Isabel, sua irmã bastarda, Ceci teria "dous cativos" prontos a fazer-lhe as vontades: um veado de estimação que criava perto da casa e o próprio Peri, que descrevia como "outro animal selvagem". ${ }^{39}$ Embora Ceci se apressasse em defendê-lo para a prima, a quem acusava de tratar injustamente o "pobre índio", o próprio Peri parecia dar razão a Isabel. Sempre pronto a satisfazer a vontade da filha de D. Antonio, ele se apresentava "tímido e submisso" frente a qualquer chamado seu, e se esmerava em satisfazer suas vontades e caprichos. Como explicava o narrador, tratava-se de uma "idolatria fanática": "amava Ceci não para sentir um prazer ou ter uma satisfação, mas para dedicar-se inteiramente a ela, para cumprir o menor dos seus desejos, para evitar que a moça tivesse um pensamento que não fosse inteiramente realidade" ${ }^{40}$ Longe de ser o resultado de uma paixão romântica entre iguais, tal devoção era explicada como reflexo da posição de superioridade em que o próprio índio colocava a filha de D. Antonio Mariz. Configurava-se assim uma relação de absoluta subordinação entre os dois protagonistas que marcava todo o desenvolvimento do romance, no qual Peri deliberadamente era apresentado como um "índio humilde e submisso". 41

Ceci, por sua vez, parecia também muito ciosa de sua posição. Por um lado, preocupava-se verdadeiramente com o índio, mostrando o desejo de ser para ele "o bom anjo de Deus, o seu gênio protetor". ${ }^{42}$ Por outro, no entanto, fazia questão de marcar seu lugar de superioridade, que tratava sempre de reafirmar. É o que deixa claro um diálogo entre os dois, no momento em que a jovem dava ao índio um par de pistolas para se defender:

- Quando correres algum perigo, lembra-te que Cecília as deu para defenderem e salvarem a tua vida.

- Por que é tua, não é, senhora?

- Sim, porque é minha, e quero que a conserves para mim. ${ }^{43}$

\footnotetext{
${ }^{39} I d .$, ib., parte I, capítulo 5, p. 48.

${ }^{40} I d$., ib., parte I, capítulo 9, p. 91.

${ }^{41} I d$., ib., parte II, capítulo 2, p. 21.

${ }_{42} I d$., ib., parte III, capítulo 8, p. 91.

${ }^{43}$ Id., ib., parte I, capítulo 10, p. 103.
} 
De início, a cena expõe a afeição de Ceci pelo índio. Preocupada com sua integridade, a jovem faz questão de dar a ele as armas para se defender. O modo pelo qual o faz, no entanto, evidencia a maneira como ela entendia aquela relação. Se, de um lado, o próprio Peri colocava sua vida como propriedade da jovem, ela tratava de reforçar esta ideia, descrevendo o índio como uma de suas propriedades. Ao longo do romance, evidencia-se assim o prazer da jovem em "ver aquela alma de selvagem (...) prostrar-se aos seus pés submissa, vencida, escrava". ${ }^{44}$

A partir da relação entre um índio que se reconhece como vassalo de sua senhora, e uma jovem que o toma como protegido sem deixar de reafirmar sua superioridade sobre ele, configurava-se entre Peri e Ceci um tipo de subordinação cuja lógica os contemporâneos de Alencar conheciam bem. Em plena vigência de uma ideologia paternalista que levava os senhores a se auto representar como protetores de seus cativos, era a partir da gramática da escravidão que se configuravam os laços entre os dois protagonistas do romance. Se restasse sobre isso alguma dúvida, o próprio Alencar trataria de dirimi-la, fazendo questão em vários momentos de definir o índio como "escravo" da jovem - um "escravo humilde que obedecia ao seu menor gesto", um "escravo fiel e dedicado" que faria de tudo para proteger Ceci. ${ }^{45}$ Reafirmada desde os capítulos iniciais pelo narrador, a imagem é colocada também na boca do próprio Peri, que se define abertamente como "escravo da senhora", e mesmo frente aos perigos que se anunciavam no fim da trama reafirmava que "o escravo não pode abandonar sua senhora". ${ }^{46}$

Com instintos nobres, Peri se mostrava consciente de seu papel, e obedecia fielmente às ordens da jovem e de seu pai. Sua única "desobediência" se dá em um momento no qual a vida de sua senhora se encontrava a perigo. Frente à objeção colocada por Dom Antonio Mariz e por Ceci ao seu plano de deixar o Paquequer para combater os perigos que ameaçavam a vida dos moradores da comunidade, Peri se mostrava confuso. "Podia o escravo resistir a uma súplica de sua senhora e acusarlhe uma mágoa, quando toda a sua vida fora destinada a fazê-la alegre e feliz?", perguntava-se o narrador. A resposta do índio veio no momento em que a jovem, exercendo sua autoridade, deixou de lado o tom ameno da relação habitual para lhe dar "uma ordem" direta para que ficasse. " Peri é livre", gritou o índio "fora de si", afirmando que faria então "o que

\footnotetext{
${ }^{44} I d$., ib., parte II, capítulo 4, p. 46.

45 Id., ib., parte I, capítulo 5, p. 46; parte I, capítulo 10, p. 105; parte II, capítulo 4, p. 53; e parte III, capítulo 12, p. 131. No total são 29 as menções de Alencar no romance à palavra "escravo", quase sempre para se referir a Peri.

${ }^{46} I d$., ib., parte II, capítulo 4, p. 47; e parte IV, capítulo 10, p. 101.
} 
lhe manda o coração", saindo em seguida da propriedade para realizar seu plano. 47

Configurava-se de lado a lado, através desse episódio, uma lógica de submissão escrava baseada não na violência, mas na fidelidade e na abnegação. Mesmo quando o fidalgo o ameaça de punição, o índio não desiste de fazer o que lhe cabia, defendendo com a própria vida o bemestar de sua senhora. Já Ceci, que em outros momentos evitava recorrer à força para afirmar sua posição de domínio - chegando a afirmar que não queria Peri como "escravo", mas apenas que ele estimasse "sua senhora" 48 - tenta exercer com mais força seu poder sobre ele no momento em que tentava garantir sua própria integridade. Nos dois casos, era através do afeto paternalista que se configurava aquela relação de dependência, que nem por isso deixava de afirmar sua marca hierárquica.

Através da relação entre Peri e Ceci, José de Alencar forjava assim um quadro no qual a escravidão aparecia como uma relação nobre, contraposta a outras formas de hierarquia baseadas no interesse. "Homens mercenários que vendem a sua coragem, a sua liberdade, a sua consciência e a sua vida por um ganho, não têm dedicação verdadeira senão a um objeto - o dinheiro", comentava o narrador em outro momento do romance. ${ }^{49}$ Em oposição a esta lógica, a harmonia entre os dois protagonistas era apresentada como um traço de grandeza de parte a parte, o que reafirmava a nobreza dos dois protagonistas.

\section{Os perigos da insubordinação}

Para além da caracterização dos personagens principais e das relações entre eles, era no desenvolvimento do romance que o sentido do mito inaugural de Alencar acabaria por se evidenciar. Se as relações entre a família de D. Antonio Mariz e seus diferentes dependentes (aí incluído o "escravo" Peri) eram de início apresentadas como harmônicas, a trama aponta para os desafios colocados a esta harmonia, que acabam por definir o sentido do romance.

Estes começam a se apresentar ainda no terceiro capítulo, que acompanha uma "bandeira" composta por cerca de quinze cavaleiros bem armados que retornavam ao Paquequer depois de uma estadia de cinco dias no Rio de Janeiro. Dirigindo a expedição, Álvaro de Sá, um dos mais fiéis cavaleiros de D. Antonio Mariz e pretendente de sua filha, tentava apressar o grupo para que pudessem voltar no mesmo dia à propriedade. Contrapondo-se a ele, um dos aventureiros, "com um

\footnotetext{
${ }^{47} I d$., ib., parte II, capítulo 12, pp. 134-136.

${ }^{48} I d$., ib., parte II, capítulo 14, p. 175.

${ }^{49} I d$., ib., parte II, capítulo 3, p. 36.
} 
ligeiro acento italiano", o arguiu sobre o motivo da pressa. Tratava-se de Loredano, apresentado como um "sarcástico italiano" que o narrador, mais a frente, explicaria tratar-se de um frade que renegou a batina, buscando abrigo na propriedade do fidalgo. ${ }^{50}$ Com malícia, ele sugeria que a pressa de Álvaro se ligava a motivos pessoais: sua vontade de reencontrar logo a jovem Ceci, que o italiano flagrara como alvo de seus galanteios antes da partida. Contestado pelo cavaleiro, Loredano reconhece que lhe devia "obediência", mas continuava ainda assim a provocá-lo. Frente à sua insistência Álvaro ameaçou castigá-lo, esmagando sua cabeça "como a uma cobra venenosa". O italiano respondeu com outra ameaça feita com uma "expressão de energia e maldade": a de contar a todos o segredo que presenciara. ${ }^{51}$ Se Peri e Ceci representavam a harmonia perfeita das relações de dependência que marcaria a relação entre a nobreza portuguesa e o mundo nativo, $o$ estrangeiro Loredano aparecia como a primeira ameaça a essa lógica, desrespeitando acintosamente a hierarquia à qual estava submetido.

Junto ao perigo de quebra do princípio da submissão por parte do estrangeiro, outro contratempo que dá movimento à trama aparece no capítulo 6. Em conversa com D. Antonio Mariz, seu fiel escudeiro comentava o assassinato de uma índia por parte de D. Diogo, filho do nobre. Para ele, tratava-se de uma "imprudência" sem maiores consequências. Para D. Antonio, no entanto, o ato representava "uma barbaria, uma loucura". "- Um fidalgo que mata uma criatura fraca e inofensiva comete uma ação baixa e indigna", explicava o nobre, que afirmava não desculpar o próprio filho. Ainda assim, o que o fazia temer era a esperada reação dos índios Aimorés, povo do qual fazia parte a índia assassinada. " - Conheces tão bem como eu (...) o caráter desses selvagens; sabes que a sua paixão dominante é a vingança, e que por ela sacrificam tudo, a vida e a liberdade", explicava ao seu acompanhante, temendo a guerra que poderia ser resultado do ato do filho. ${ }^{52}$

Configuravam-se, com isso, os dois perigos que ameaçavam a paz do Paquequer: a quebra do princípio da subordinação, representada pela ação de Loredano, e o rompimento da harmonia entre os nobres portugueses e os povos nativos. Juntos, esses dois eventos colocavam à prova a ordem afirmada nos capítulos iniciais, alimentando a trama do romance. Se a relação entre Peri e Ceci representava idealmente o caminho de construção da civilização que se tentava afirmar no Paquequer, a ação de sujeitos que não tinham o mesmo instinto de nobreza - fosse o italiano movido somente por interesses ou os

\footnotetext{
${ }^{50}$ Id., ib., parte I, capítulo 3, p. 23; e parte III, capítulo 11, p. 124.

${ }^{51} I d .$, ib., parte I, capítulo 3, pp. 25-31.

${ }^{52} I d$., ib., parte I, capítulo 6, pp. 57-59.
} 
selvagens Aimorés em busca de vingança - representava a principal ameaça ao mundo constituído por D. Antonio Mariz.

Era como resultado do desenvolvimento dessas duas questões que, em pouco tempo, a ordem daquele mundo chegaria ao fim. Alertado por Peri, o fidalgo descobre que os Aimorés planejavam um ataque à comunidade para vingar a morte da índia. ${ }^{53}$ No momento em que seus habitantes deviam estar mais unidos para se proteger do perigo, no entanto, disseminava-se entre os dependentes locais o mal da insubmissão instigado por Loredano. Em atitude de "traição", parte deles participaria de uma conspiração comandada pelo italiano para assassinar a família do fidalgo e os seus aventureiros mais fiéis, e sequestrar Ceci. ${ }^{54}$ Descoberto por Peri, que impede que o plano se consume, Loredano passou a incitar "os aventureiros à revolta". Em reunião com D. Antonio Mariz, o italiano reclamava em nome dos aventureiros de que eles seriam "tratados como cães". "- Não somos escravos!", protestava outro membro do grupo frente ao fidalgo, que respondeu afirmando que os revoltosos seriam "menos que escravos", por serem "traidores infames e hereges". Estava definitivamente rompida, desse modo, a harmonia entre o senhor e seus dependentes. ${ }^{55}$

Quando os Aimorés se aproximam do Paquequer, já não havia por isso forças para resistir à investida. Frente à inevitável derrocada, o fidalgo se mostrava pronto a defender seu território com a própria vida. Disposto a poupar a filha, no entanto, convence Peri a ser batizado na religião católica, de modo a poder dar a ele seu nome e a responsabilidade, tomada sob juramento, de zelar pela segurança de Ceci. ${ }^{56}$ Parecia, com isso, perceber que a única forma de salvar a herança da civilização que construiu ali era entregá-la aos cuidados de um representante do mundo nativo, fundando as bases de um outro tipo de civilização. Tomando a jovem nos braços, Peri realiza o desejo do nobre, tirando-a do Paquequer enquanto os inimigos invadiam a propriedade. De longe, assistiu ao heroico ato final de D. Antonio - que explode o paiol de pólvora, destruindo a casa para evitar que ela caísse nas mãos dos índios selvagens. ${ }^{57}$

Configurava-se, com isso, o sentido do enredo: enquanto a quebra do princípio da submissão levou o Paquequer à destruição, era justamente sua manutenção que garantiria a vida dos dois protagonistas. Remando incansavelmente pelo rio, Peri afastava a jovem do perigo e da destruição. A dar-lhe forças estava "a ideia de que ia salvar sua senhora e

\footnotetext{
${ }^{53} I d .$, ib., parte I, capítulo 10, p. 252.

${ }^{54} I d .$, ib., parte III, capítulo 4, pp. 45-47.

${ }^{55} \mathrm{Id}$., ib., parte III, capítulo 6, pp. 65-74.

${ }^{56} I d .$, ib., parte IV, capítulo 10, pp. 102-104.

${ }^{57}$ Id., ib., parte IV, capítulo 10, pp. 105-109.
} 
cumprir o juramento que tinha feito ao velho fidalgo", em atitude que reafirmava sua devoção e submissão à família do nobre. ${ }^{58}$ Destruído o mundo criado por D. Antonio, esta submissão podia se expressar de forma mais natural na floresta, onde "desapareciam" as distinções e hierarquias que marcavam a civilização europeia implantada pelo fidalgo nos trópicos. Em um momento de descanso, o índio reafirmava à jovem sua subordinação: " - Peri... é teu escravo", afirmava a Ceci. Despida das formalidades de seu mundo, a jovem o contesta: "tu és meu irmão", respondeu com um sorriso. ${ }^{59}$ Ainda que a relação de subordinação se mantivesse inalterada, ela podia se manifestar sem as formalidades e hierarquias que marcavam o mundo tradicional de D. Antonio, e que se reafirmariam caso os dois se dirigissem à cidade - onde Peri seria novamente tratado como "um cativo, tratado por todos com desprezo". 60 Ao optar pela vida nas matas, os dois protagonistas passavam a representar a submissão fraterna construída entre eles, aclimatada à realidade natural da região em que viviam.

Antes que o romance acabasse, no entanto, ainda viria o dilúvio. Prenunciando a tempestade, Peri carregou a jovem para a parte alta de uma palmeira, esperando de lá a enxurrada. Quando ela veio, sua intensidade era tanta que ameaçava encobrir a própria árvore, ameaçando a vida dos dois. Nesse momento, com força "sobre-humana", Peri protagoniza "um espetáculo grandioso": mesmo estando em cima da árvore, consegue arrancá-la do chão, fazendo de seu tronco o barco que garantiria a vida dos dois protagonistas - em cena que desnudava o singular princípio de realidade que regia o mito inaugural de Alencar, no qual a busca da verdade profunda não se deixava limitar pela prisão da verossimilhança. $61 \mathrm{Em}$ meio à "torrente impetuosa" decorrente da tempestade, os dois sumiam no horizonte para um destino apenas sugerido.

Evidenciava-se, neste epílogo, o sentido da imagem da Arca de Noé citada por Alencar em seu prólogo: como na mitologia bíblica, as águas do dilúvio vinham varrer as impurezas e vícios do passado, na constituição de um novo futuro que se iniciava. Delas sobreviveriam apenas o que de melhor havia de cada uma das duas civilizações do Paquequer, ambas com "a mesma grandeza de alma e a mesma nobreza de sentimentos", entre as quais as "circunstâncias da vida" civilizada haviam criado "contrastes" ${ }^{62}$ Superados estes formalismos, era a lógica de uma subordinação sincera e desinteressada que garantia a

\footnotetext{
${ }^{58} I d .$, ib., parte IV, "Epílogo", p.115.

${ }^{59} \mathrm{Id}$., ib., parte IV, "Epílogo", p.133.

${ }^{60} I d$., ib., parte IV, "Epílogo", p. 142.

${ }^{61} \mathrm{Id}$., ib., parte IV, capítulo 11, pp. 166-167.

${ }^{62} I d$., ib., parte I, capítulo 14, p. 172.
} 
sobrevivência dos protagonistas, que reestabeleciam a harmonia perdida pela quebra das hierarquias decorrentes dos laços de dependência.

Alencar mostrava com isso cumprir fielmente o desafio no qual Gonçalves de Magalhães falhara: o de apresentar um retrato fiel da nacionalidade, capaz de representar efetivamente as condições e desafios sobre os quais ela se construía. Nexos fundamentais da sociedade brasileira do período, a escravidão e as relações de dependência estavam na base do mito inaugural de Alencar, alegorizados pela completa e desinteressada submissão de Peri a Ceci. Era sobre estes princípios, e não sobre qualquer proposta de miscigenação, que se delineava o sentido do enredo - como mostra o caso de Isabel, a filha de Dom Antonio com uma índia. Única mestiça do romance, ela é caracterizada com uma licenciosidade e fraqueza que acabam por levá-la ao suicídio, na demonstração do quanto o autor compartilhava das ideias de seu tempo sobre a degeneração decorrente dos cruzamentos raciais ${ }^{63}$. Da relação final entre os dois protagonistas resulta assim não o início de um novo povo biologicamente determinado pelo cruzamento, mas a base moral de uma nação que, sob o prisma da religiosidade e com a herança da civilização portuguesa, se constituiria a partir do respeito a esses laços fundamentais de submissão. Afirmava-se, com isso, o sentido ideológico do mito inaugural de Alencar, que no mesmo movimento em que afirmava a unidade tratava de justificar a desigualdade própria da sociedade brasileira - em perspectiva que voltaria a exercitar, nos anos seguintes, frente a novos desafios colocados a essa ordem.

Leonardo Affonso de Miranda Pereira é professor associado do Departamento de História da Pontifícia Universidade Católica do Rio de Janeiro. Possui graduação em Ciências Sociais pela Universidade Estadual de Campinas (1991), com Mestrado (1994) e Doutorado (1998) em História Social pela mesma universidade. Atua na área de História do Brasil, em especial do Segundo Reinado e da Primeira República. Seus interesses de investigação se voltam para os processos de conexão e embate cultural entre diferentes grupos sociais - com ênfase no associativismo recreativo dos trabalhadores, na produção de literatos e homens de jornal e na constituição social dos símbolos da nacionalidade. Contato: leonardo@puc-rio.br

${ }^{63} I d$., ib., parte I, capítulo 2, pg. 19; e parte IV, capítulo 13, pp. 84-87. Sobre a afirmação dos prejuízos da mestiçagem no período, ver SCHWARCZ, Lilia Moritz. O espetáculo das raças. Cientistas, instituições e questão racial no Brasil, 1870-1930. São Paulo: Cia. das letras, 1993, pp. 43-66. 